\title{
Yield and content of essential oils in the common origanum nursery
}

\author{
Maria Reneva ${ }^{1}$, Valeriy Gubanov ${ }^{1,}{ }^{*}$, and Vera Gubanova ${ }^{2}$ \\ ${ }^{1}$ Federal State Institutions Federal Research Centre Tyumen Scientific Centre of Siberian Branch of \\ the Russian Academy of Sciences (Tyumen Scientific Centre SB RAS), Tyumen, Russia \\ ${ }^{2}$ Federal State Budgetary General Educational Institution of Higher Education "State Agrarian \\ University of the Northern Trans-Urals", Tyumen, Russia
}

\begin{abstract}
Common origanum is one of the most famous spices, it is popular all over the world. The purpose of this work is to conduct a comparative assessment of the yield of raw plant materials and the content of essential oils in common origanum plants. Field research was carried out in 2019-2020 at the experimental field of the Northern Trans Urals Research Institute - a branch of the Tyumen Research Center SB RAS (Moskovsky settlement of the Tyumen district). The soil of the experimental site belongs to the subtype of dark gray forest, heavy loamy according to the granulometric composition. From the studied 350 common origanum samples, 16 samples were isolated. All samples were evaluated according to the following criteria: the yield of raw plant materials and the amount of essential oil. The Khutoryanka variety is accepted as the standard. For two years of research, three samples were distinguished from the studied samples of common origanum in terms of the yield of raw plant materials compared to the standard: 12-2-2; 13-2-1; $15-2-1$, the yield of these numbers was from 3.6 to $3.9 \mathrm{t} / \mathrm{ha}$, this is $(13.3$, $10.0,6.6 \%$ ) higher than the standard. From the studied samples of common origanum, two samples were distinguished by the content of essential oils in dry plant materials - 14-2-3 and 21-1-1. The harvest per hectare of these samples was, respectively, 750 and $928 \mathrm{ml}$ in 2019, and in 2020,1026 and $1120 \mathrm{ml} / \mathrm{ha}$.
\end{abstract}

\section{Introduction}

Common origanum (Origanum vulgareL.) is a perennial herbaceous plant from the Lamiaceae family [1]. The culture originates from the countries of the Mediterranean Sea and grows almost everywhere (except in the Far North). In Russia, it grows on the forest edges, among shrubs, on dry, floodplain and forest meadows, in river valleys $[2,3,4]$.

The plant is known and very popular in official and folk medicine in many countries of the world. The aboveground part of the plant helps to improve the activity of the gastrointestinal tract, it is part of the sedative tea for the treatment of neuroses, thereby strengthening the human immune system. Externally, it is used for lotions and medical

\footnotetext{
*Corresponding author: mihail-gubanoff.1987@yandex.ru
} 
procedures, improves skin color and promotes its firmness and elasticity - this is necessary for residents of the Far North where sunlight is in short supply. Preparations from origanum are used for diseases of the central and nervous system, hypertension, stroke, has a local anti-inflammatory, analgesic and antiseptic effect. This remedy is able to support the body not only for colds, but also in the period after a viral infection. Infusion of origanum flowers has an immunostimulating effect on the immunoglobulin composition of blood serum in one and two-month-old calves $[1,2,5]$.

As a spice, the plant is added to vegetable, cereal, fruit and berry dishes. The leaves are used in the production of sausages, as a substitute for tea, when pickling and salting. As a dye, it is used in the preparation of black and brown paints. This is an excellent vegetable natural dye for infusions of teas and juices. It can also be used as an ornamental plant and a nectariferous plant. Bees collect fragrant medicinal nectar with the advantages listed above. Honey is known to have another amazing advantage - it is its genetic digestibility in the human body, developed over thousands of years of using origanum [9-11].

The chemical composition of common origanum is rich in micro- and macroelements, vitamins $\mathrm{C}, \mathrm{B} 1, \mathrm{~B} 2$. Biologically active substances are represented by flavonoids, tannins. The most valuable essential oil in the plant is considered to be consisting of a mixture of nitrogen-free substances with an aromatic smell. The composition of the essential oil includes $20 \%$ thymol, carvacrol, cymene, thujone, dipentene and turpentine. Essential oil is used for the fragrance of soap, the production of toilet water. Up to $28 \%$ of fatty oil was found in the seeds $[6,12]$.

The purpose of the work is to conduct a comparative evaluation of the yield of raw plant materials and the content of essential oils in common origanum plants.

\section{Materials and methods}

Field studies were conducted in 2019-2020 at the experimental field of the Northern TransUrals Research Institute - a branch of the Tyumen Scientific Research Center of the SB RAS (Moskovsky settlement, Tyumen district), located in the northern forest-steppe, which is characterized by a sharply continental climate characterized by cold, long winters and short, moderately hot summers. According to the indicator of precipitation availability, the growing season of 2019 was sufficiently moist and corresponded to the average annual precipitation rate. 2020 was insufficiently provided with precipitation $-169 \mathrm{~mm}$ of precipitation fell during the period of the 3rd decade of May - the 1st decade of September, i.e. $72 \%$ of the average annual indicator.

During the flowering period of plants, 2019 was cool - below $20^{\circ} \mathrm{C}$. The flowering period in 2020 fell on a temperature regime above $20^{\circ} \mathrm{C}$, which contributed to a greater yield of essential oil.

The soil of the experimental site belongs to the subtype of dark gray forest, heavy loamy according to the granulometric composition. It has quite favorable physical and chemical properties. The humus horizon has a low density $(1.22 \mathrm{~g} / \mathrm{cm} 3)$. The humus content is $4.3 \%$. The content of nitrate nitrogen in the soil of the studies is low $(1.36-2.38 \mathrm{mg} / 100 \mathrm{~g}$ of soil), phosphorus is average $(8.25-14.1 \mathrm{mg} / 100 \mathrm{~g}$ of soil), potassium is above average $(6.65-8.9 \mathrm{mg} / 100 \mathrm{~g}$ of soil), the reaction of the soil solution is slightly acidic (5.1-6.0).

From the studied 350 samples of common origanum, 16 samples were identified, characterized by valuable economic and useful signs. The studied samples were taken from different districts of the south of the Tyumen region - these are Yalutorovsk, Golyshmanovsk, Omutinsk, Yurginsk, Zavodoukovsk, Tyumen districts. The nursery is laid out according to the scheme of $0.3 \times 0.6 \mathrm{~m}$. All samples were evaluated according to the following criteria: the yield of raw plant materials and the content of essential oil in dry raw materials. The Khutoryanka variety is accepted as the standard. The yield of plant materials 
was determined by weighing the aboveground part of the plant cut at a height of $7-8 \mathrm{~cm}$ from the soil surface. The aboveground part of the plants was dried by air-shade method. The mass fraction of essential oil was determined in the phase of full flowering of plants by the Ginsberg hydrodistillation method [7].

\section{Results and discussion}

The yield of raw plant materials of common origanum samples is shown in Table 1.

Table 1. Yield of raw plant materials of common origanum samples.

\begin{tabular}{|c|c|c|c|c|c|}
\hline No. & $\begin{array}{c}\text { Collection } \\
\text { number }\end{array}$ & $\begin{array}{c}\text { Yield of 2019, } \\
\text { t/ha }\end{array}$ & $\begin{array}{c}\text { Yield of 2020, } \\
\text { t/ha }\end{array}$ & $\begin{array}{c}\text { Deviation } \\
\text { from the } \\
\text { standard, } \\
\mathbf{2 0 1 9 ,} \mathbf{\%}\end{array}$ & $\begin{array}{c}\text { Deviation } \\
\text { from the } \\
\text { standard, } \\
\mathbf{2 0 2 0} \mathbf{\%}\end{array}$ \\
\hline 1 & $\mathrm{St}$ & 3.4 & 3.0 & - & - \\
\hline 2 & $2-2-4$ & 3.2 & 2.9 & -5.9 & -3.3 \\
\hline 3 & $3-1-3$ & 3.3 & 3.0 & -2.9 & 0 \\
\hline 4 & $4-1-2$ & 3.3 & 3.0 & -2.9 & 0 \\
\hline 5 & $8-2-3$ & 3.4 & 2.8 & 0 & -6.6 \\
\hline 6 & $9-1-3$ & 3.5 & 3.0 & +2.9 & 0 \\
\hline 7 & $11-2-4$ & 3.3 & 2.9 & -2.9 & -3.3 \\
\hline 8 & $12-2-2$ & 3.9 & 3.4 & +14.7 & +13.3 \\
\hline 9 & $13-2-1$ & 3.8 & 3.3 & +11.8 & +10.0 \\
\hline 10 & $14-2-3$ & 3.0 & 2.7 & -11.8 & -10.0 \\
\hline 11 & $15-2-1$ & 3.6 & 3.2 & +5.9 & +6.6 \\
\hline 12 & $16-1-1$ & 3.2 & 3.0 & -5.9 & 0 \\
\hline 13 & $17-2-2$ & 3.2 & 2.8 & -5.9 & -6.6 \\
\hline 14 & $18-1-3$ & 3.4 & 2.9 & 0 & -3.3 \\
\hline 15 & $20-2-2$ & 3.0 & 2.8 & -11.8 & -6.6 \\
\hline 16 & $21-1-1$ & 3.2 & 2.8 & -5.9 & -6.6 \\
\hline
\end{tabular}

In 2019, the yield of raw plant materials ranged from $3.0 \mathrm{t} / \mathrm{ha}(20-2-2)$ to $3.9 \mathrm{t} / \mathrm{ha}(12-2-$ 2 ), the maximum yield of raw materials was obtained from samples 12-2-2 (3.9 t/ha), 13-2$1(3.8 \mathrm{t} / \mathrm{ha})$, which is $14.7 \%$ and $11.8 \%$ higher than the standard, respectively. More than $3.4 \mathrm{t} / \mathrm{ha}$ was obtained from two samples: 15-2-1 (3.6 t/ha) and 9-1-3 (3.5 t/ha). Two samples were shown at the standard level: $8-2-3$ (3.4 t/ha) and 18-1-3 (3.4 t/ha). The remaining numbers showed the lowest yield from $3.0 \mathrm{t} / \mathrm{ha}$ to $3.3 \mathrm{t} / \mathrm{ha}$.

In 2020, the variation in the yield of plant materials ranged from $2.8 \mathrm{t} / \mathrm{ha}$ to $3.4 \mathrm{t} / \mathrm{ha}$. At the standard level, four samples were distinguished: 3-1-3; 4-1-2; 9-1-3; 16-1-1 with a yield of $3.0 \mathrm{t} / \mathrm{ha}$. High indicators were noted in samples 12-2-2 (3.4 t/ha) and 13-2-2 (3.3 t/ha), samples showed below the standard: 14-2-3; 8-2-1; 17-2-2; 20-2-2; 21-1-1; 2-2-4; 11-2-4; 18-1-3 their yield ranged from 2.7 to $2.9 \mathrm{t} / \mathrm{ha}$.

For two years of research, three samples were distinguished from the studied samples of common origanum in terms of the yield of raw plant materials compared to the standard: $12-2-2 ; 13-2-1 ; 15-2-1$, the yield of these numbers was from 3.6 to $3.9 \mathrm{t} / \mathrm{ha}$, this is $(13.3$, $10.0,6.6 \%$ ) higher than the standard.

The content of essential oils in dry plant materials of wild samples of common origanum is shown in Table 2. 
Table 2. The content of essential oils in dry plant materials of common origanum samples.

\begin{tabular}{|c|c|c|c|c|c|}
\hline $\begin{array}{l}\mathbf{N} \\
\mathbf{0} .\end{array}$ & $\begin{array}{c}\text { Collection } \\
\text { number }\end{array}$ & $\begin{array}{c}\text { Essential oil } \\
\text { content, } \\
\text { ml/kg dry. } \\
\text { matter, } 2019\end{array}$ & $\begin{array}{c}\text { Essential oil } \\
\text { content, } \mathrm{ml} / \mathrm{kg} \\
\text { dry. } \text { matter, } 2020\end{array}$ & $\begin{array}{l}\text { Deviation from } \\
\text { standard, } \\
2019, \%\end{array}$ & $\begin{array}{c}\text { Deviation from } \\
\text { standard, 2020, } \\
\%\end{array}$ \\
\hline 1 & $\mathrm{St}$ & 0.21 & 0.30 & - & - \\
\hline 2 & $2-2-4$ & 0.07 & 0.10 & -66.6 & -66.6 \\
\hline 3 & $3-1-3$ & 0.07 & 0.12 & -66.6 & -60.0 \\
\hline 4 & $4-1-2$ & 0.05 & 0.11 & -76.2 & -63.3 \\
\hline 5 & $8-2-3$ & 0.05 & 0.10 & -76.2 & -66.6 \\
\hline 6 & $9-1-3$ & 0.09 & 0.17 & -57.1 & -43.3 \\
\hline 7 & $11-2-4$ & 0.19 & 0.34 & -9.5 & +13.3 \\
\hline 8 & $12-2-2$ & 0.15 & 0.22 & -28.6 & -26.6 \\
\hline 9 & $13-2-1$ & 0.13 & 0.21 & -38.1 & -30.0 \\
\hline 10 & $14-2-3$ & 0.25 & 0.38 & +19.0 & +26.6 \\
\hline 11 & $15-2-1$ & 0.17 & 0.28 & -19.0 & -6.6 \\
\hline 12 & $16-1-1$ & 0.14 & 0.21 & -33.3 & -30.0 \\
\hline 13 & $17-2-2$ & 0.16 & 0.26 & -23.8 & -13.3 \\
\hline 14 & $18-1-3$ & 0.16 & 0.28 & -23.8 & -6.6 \\
\hline 15 & $20-2-2$ & 0.15 & 0.27 & -28.6 & -10.0 \\
\hline 16 & $21-1-1$ & 0.29 & 0.40 & +38.0 & +33.3 \\
\hline
\end{tabular}

In 2019, the maximum yield of essential oil was shown by the numbers: 21-1-1 (0.29 $\mathrm{mg} / \mathrm{kg}$ dry. matter); $14-2-3(0.25 \mathrm{mg} / \mathrm{kg}$ dry. matter $)$, which is $33.3 \%$ and $26.6 \%$ higher than the standard, respectively. The minimum yield of essential oils was obtained from samples: $8-2-3 ; 4-1-2 ; 3-1-3$, the oil content varied from 0.05 to $0.07 \mathrm{mg} / \mathrm{kg}$ of dry matter. Samples 11-2-4, 12-2-2-, 13-2-1, 15-2-1, 16-1-1, 17-2-2, 18-1-3, 20-2-2 were characterized by a low content of essential oil compared to the standard, their indicators ranged from 0.13 to 0.19 $\mathrm{mg} / \mathrm{kg}$.

In 2020, the highest content of essential oil was observed in samples 21-1-1 (0.40 $\mathrm{mg} / \mathrm{kg}), 14-2-3(0.38 \mathrm{mg} / \mathrm{kg})$ and $11-2-2(0.34 \mathrm{mg} / \mathrm{kg})$. The indicator of essential oil was lower than the standard in the samples 16-1-1, 13-2-1, 12-2-2, 17-2-2, 20-2-2, 18-1-3, 15-21 , it ranged from $0.21-0.28 \mathrm{mg} / \mathrm{kg}$. The remaining samples $2-2-4,8-2-3,4-1-2,3-1-3$ had a minimum accumulation of essential oil from $0.10-0.12 \mathrm{mg} / \mathrm{kg}$.

From the studied samples of common origanum, according to the content of essential oils in dry plant materials, two samples were distinguished in 2019 (Table. 3): 21-1-1 (0.29 $\mathrm{mg} / \mathrm{kg}), 14-2-3(0.25 \mathrm{mg} / \mathrm{kg})$. In 2020, samples 21-1-1 and 14-2-3 were characterized by a high content of essential oil compared to 2019 , which amounted to $0.40 \mathrm{mg} / \mathrm{kg}$ and 0.38 $\mathrm{mg} / \mathrm{kg}$ of dry matter, respectively. In 2020, sample 11-2-4 with an essential oil yield of 0.34 $\mathrm{mg} / \mathrm{kg}$ was $13.3 \%$ higher than the standard, and in 2019 its yield was $0.19 \mathrm{mg} / \mathrm{kg}$ and was 9.5\% lower than the standard.

In 2019, samples 14-2-3, 14-2-3 had an advantage in terms of the yield of essential oil per hectare and exceeded the standard by 5 and $30 \%$, respectively.

In 2020, in comparison with the standard for the yield of essential oil, the following were distinguished 11-2-4 (by $9.6 \%$ ) and 14-2-3 (by $24.4 \%$ ).

Table3. The yield of essential oil in samples of common origanum in terms of per hectare

\begin{tabular}{|c|c|c|c|c|c|c|c|}
\hline \multirow{2}{*}{ No. } & \multirow{2}{*}{$\begin{array}{c}\text { Collection } \\
\text { number }\end{array}$} & $\mathbf{m l} / \mathbf{h a}$ & $\begin{array}{c}+/- \text { to the } \\
\text { standard, } \\
\mathbf{\%}\end{array}$ & $\mathbf{m l} / \mathbf{h a}$ & $\begin{array}{c}+/- \text { to the } \\
\text { standard, } \\
\mathbf{\%}\end{array}$ & $\mathbf{m l} / \mathbf{h a}$ & $\begin{array}{c}+/- \text { to the } \\
\text { standard, } \\
\mathbf{\%}\end{array}$ \\
\hline 1 & $\mathrm{St}$ & 714 & - & 900 & - & 807 & - \\
\hline 2 & $2-2-4$ & 224 & -68.6 & 290 & -67.8 & 257 & -68.2 \\
\hline
\end{tabular}




\begin{tabular}{|c|c|c|c|c|c|c|c|}
\hline 3 & $3-1-3$ & 231 & -67.6 & 360 & -60.0 & 296 & -63.4 \\
\hline 4 & $4-1-2$ & 165 & -76.9 & 330 & -63.3 & 248 & -69.3 \\
\hline 5 & $8-2-3$ & 170 & -76.2 & 280 & -68.9 & 225 & -72.1 \\
\hline 6 & $9-1-3$ & 315 & -55.9 & 510 & -43.3 & 413 & -48.9 \\
\hline 7 & $11-2-4$ & 627 & -12.2 & 986 & 9.6 & 807 & -0.1 \\
\hline 8 & $12-2-2$ & 585 & -18.1 & 748 & -16.9 & 667 & -17.4 \\
\hline 9 & $13-2-1$ & 494 & -30.8 & 693 & -23.0 & 594 & -26.5 \\
\hline 10 & $14-2-3$ & 750 & 5.0 & 1026 & 14.0 & 888 & 10.0 \\
\hline 11 & $15-2-1$ & 612 & -14.3 & 896 & -0.4 & 754 & -6.6 \\
\hline 12 & $16-1-1$ & 448 & -37.3 & 630 & -30.0 & 539 & -33.2 \\
\hline 13 & $17-2-2$ & 512 & -28.3 & 728 & -19.1 & 620 & -23.2 \\
\hline 14 & $18-1-3$ & 544 & -23.8 & 812 & -9.8 & 678 & -16.0 \\
\hline 15 & $20-2-2$ & 450 & -37.0 & 756 & -16.0 & 603 & -25.3 \\
\hline 16 & $21-1-1$ & 928 & 30.0 & 1120 & 24.4 & 1024 & 26.9 \\
\hline
\end{tabular}

On average, over the years of research, 14-2-3, 14-2-3 were distinguished for this indicator, which exceeded the standard by $81 \mathrm{ml} / \mathrm{ha}$ and $217 \mathrm{ml} / \mathrm{ha}$, respectively.

\section{Conclusions}

According to the results of the comparative evaluation of the content of essential oils and the yield of raw plant materials of common origanum plants, it was revealed that for two years of research, the highest yield of plant materials was shown by samples 12-2-2, 13-2-1, 15-2-1, but the yield of essential oils was below the standard.

Numbers 14-2-3 and 21-1-1 showed the highest content of essential oils, the yield of these numbers did not exceed the standard.

In 2020, numbers 14-2-3 and 21-1-1 contained the maximum amount of essential oil $1026 \mathrm{ml} / \mathrm{ha}$ and $1120 \mathrm{ml} / \mathrm{ha}$, respectively, the same trend was observed in the unfavorable 2019.

From the studied 350 samples of common origanum, the selected breeding numbers will be used in further breeding studies.

\section{References}

1. R. Pezzani, S. Vitalini, M. Iriti, Phytochem Rev 16, 1253-1268 (2017) https://doi.org/10.1007/s11101-017-9535-z

2. B. Lukas, J. Novak, Origanum vulgare L. and Origanum onites L. (Oregano). Medicinal, Aromatic and Stimulant Plants, Handbook of Plant Breeding, 12 (2020) Springer, Cham. https://doi.org/10.1007/978-3-030-38792-1_12

3. V.G. Gubanov, V.M. Gubanova, Achievements of science and technology of the agroindustrial complex, 33(3), 33-36 (2019)

4. S.V. Vishnyakova, M.V. Zhukova, Medicinal and essential oil plants, 41 (Yekaterinburg, USLTU, 2017)

5. Y. Jnaid, R. Yacoub, F. Al-Biski, antioxidant and antimicrobial activities of Origanumvulgare essential oil // International Food Research Journal. 23(4), 17061710 (2016).

6. V.S. Pashtetsky, N.V. Nevkrytaya, Tavrichesky Bulletin of Agrarian Science, 1(13), 16-38 (2018) DOI 10.25637/TVAN2018.01.02.

7. GOST 34213-2017 Essential oil flower and herbaceous raw materials. Methods of sampling, determination of moisture, impurities and essential oil The electronic text of 
the document was prepared by JSC "Codex" and verified by: official publication. Moscow: Standartinform, (2019)

8. F.M. Khazieva, V.I. Osipov, I.N. Korotkikh, Chemistry of vegetable raw materials, 4, 97-105 (2016)

9. L. Vlase, D. Hanganu, G. Damian et al. Molecules, 19(5), 5490-5507 (2014) DOI: 10.3390/molecules 19055490

10. E. Sarrou, N. Tsivelika, P. Chatzopoulou, et al., Euphytica 213, 104 (2017) https://doi.org/10.1007/s10681-017-1889-1

11. R. Nurzyñska-Wierdak, A. Bogucka-Kocka, SowaI. et all., Farmacia, 60(4), 571-77 (2012)

12. V.M. Mirovich, T.A. Konenkina, G.M. Fedoseeva, et al., Chemistry of plant raw materials, 2(61), 4 (2008) 